\title{
The influence of weight coefficients in the Preissman scheme on flows in the lower Odra river network using the Hec-Ras software
}

\author{
Robert Mańko ${ }^{1, *}$ \\ ${ }^{1}$ West Pomeranian University of Technology in Szczecin, Faculty of Civil Engineering and Architecture, Department of Water \\ Construction
}

\begin{abstract}
Mathematical modelling of water flows processes in rivers and open channels for many years has been target of researches for hydrotechnics and hydrologists. For flows forecasting in open channels models based on one-dimensional equations are mostly used. This models are assuming that the main flow component is parallel to the channel axis is substantially larger than others, so it can ignore them. One of the most effective methods for solving de Saint-Venant equations is the finite difference method with using four-point Preissman Scheme. In this paper an analysis of the impact of Preissman weighting parameters on flows in the lower Odra river network.
\end{abstract}

\section{Introduction}

\subsection{General description of lower Odra hydrography}

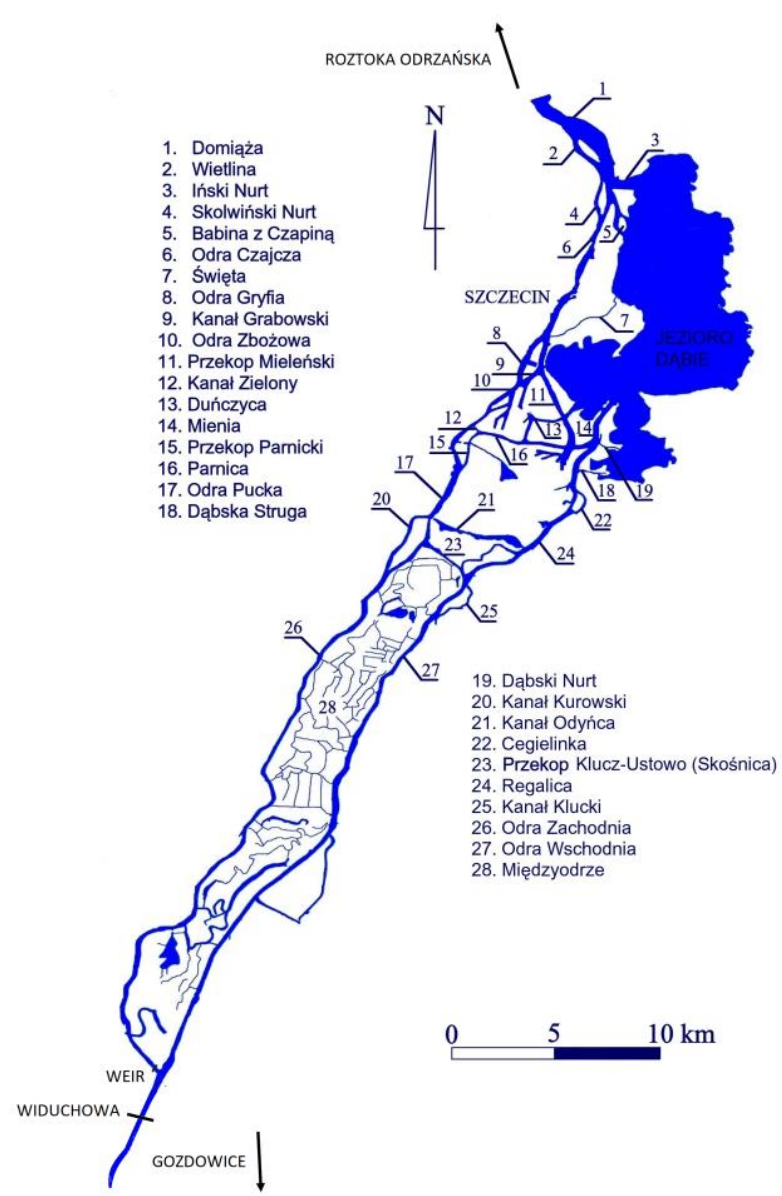

The lower Odra region from Gozdowice to Roztoka Odrzańska is very important part of Odra estuary to the Baltic Sea. The mouth of the Odra can be divided into three parts: the flow part - to Roztoka Odrzańska, Szczecin Lagoon part and part consisting of three straits Connecting the Szczecin Lagoon with Baltic Sea: Dziwna, Swina and Piana. Depending on the research criterion, the definition of lower Odra is an ambiguous definition. Over the latest years, 4 criteria have been developed [1]:

- Hydrological criterion: Lower Odra means the section from Roztoka Odrzańska (at the Trzebież level) to the cross section in Gozdowice, which is already out the influence of sea backwater [2];

- Geographical criterion: Lower Odra starts from Warta mouth and ends in Dąbie lake;

- Hydrographical criterion: By the name of lower Odra it means a section from Warta to Roztoka Odrzańska;

- Navigation criteria: Lower Odra is the section of Odra from Zatoń Górna (Odra-Havel channel) to the Long Bridge in Szczecin and Dąbie Lake.

Figure 1 presents the situation plan of the Odra estuary on the section from Widuchowa to Roztoka Odrzańska.

Fig. 1. Lower Odra situation plan, made on basis $[3,4]$.

\footnotetext{
* Corresponding author: Robert.Manko@ zut.edu.pl
} 
Gozdowice profile is located on the $645 \mathrm{~km}$ of Odra river (over $50 \mathrm{~km}$ upstream Widuchowa weir), and is cross section closest to the mouth for which flows are measured. In the section from Gozdowice to Widuchowa, the average depths of Odra range from 3 to $3.5 \mathrm{~m}$, with an average water surface of approx. $170 \mathrm{~m}$.

2 kilometres below the Widuchowa cross section, the Odra river is splitting into two main branches: the Eastern and the Western Odra. After the split, both arms are practically parallel to each other, and the area contained between these arms is called "Międzyodrze". East Odra on its length is characterized by average depth of $7.0 \mathrm{~m}$. In case of West Odra, the depths along its entire lengths are very widely, varying from 3-4 $\mathrm{m}$ in Widuchowa level to over $11 \mathrm{~m}$ in the area of Szczecin. The water surface widths of Eastern and Western Odra ranges from 140 to $180 \mathrm{~m}$. The East Odra is called section from node in Widuchowa to the Skośnica channel. East Odra then changes name to Regalica to reach Dąbie Lake after 11 kilometres. Skośnica is main navigable connection between two arms of Odra, whose average depths are equal of 3-3.5 m. A very important element in lower Odra river network, which controlled the flows is weir situated at the beginning of West Odra.

The main objective of this weir was to control the flow distribution in Widuchowa node, in order to maintain optimal water levels conditions in the Międzyodrze area, which was once intensively used for agriculture. Currently weir do not have any practical function. Flow distribution is controlled by 5 spans, the diagram of which is shown in figure 2 . Each span is divided into 8 individuals sections, which are independently closed.

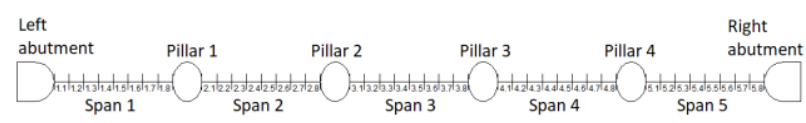

Fig. 2. Scheme of Widuchowa weir spans.

In the lower Odra river network can identify six cross section for which observations of water levels are carried out. Table 1 presents selected characteristic values for the water gauges of the lower Oder:

- SNQ - average flow from low flows for many years

- SNW - average level from low levels for many years

- SSQ - average flow from average flows for many years

- SSW - average level from average levels for many years

- SWQ - average flow from high flows for many years

- SWW - average level from high levels for many years

Table 1. Characteristic water levels on gauges and flows for lower Odra river network.

\begin{tabular}{|c|c|c|c|c|}
\hline Water gauge & $\begin{array}{c}\text { Zero of } \\
\text { water } \\
\text { gauge } \\
{[\mathrm{m} \text { a.s.1.] }}\end{array}$ & $\begin{array}{c}\mathrm{SNQ} \\
{\left[\mathrm{m}^{3} / \mathrm{s}\right]}\end{array}$ & $\begin{array}{c}\mathrm{SSQ} \\
{\left[\mathrm{m}^{3} / \mathrm{s}\right]}\end{array}$ & $\begin{array}{c}\mathrm{SWQ} \\
{\left[\mathrm{m}^{3} / \mathrm{s}\right]}\end{array}$ \\
\hline Gozdowice & 3.020 & 252 & 535 & 1251 \\
\hline
\end{tabular}

\begin{tabular}{|c|c|c|c|c|}
\hline Water gauge & $\begin{array}{c}\text { Zero of } \\
\text { water } \\
\text { gauge } \\
\text { [m a.s.1.] }\end{array}$ & $\begin{array}{c}\text { SNW } \\
\text { [m a.s.1.] }\end{array}$ & $\begin{array}{c}\text { SSW [m } \\
\text { a.s.1.] }\end{array}$ & $\begin{array}{c}\text { SWW } \\
\text { [m a.s.1.] }\end{array}$ \\
\hline Gozdowice & 3.020 & 208 & 322 & 492 \\
\hline Widuchowa & -5.157 & 479 & 545 & 652 \\
\hline $\begin{array}{c}\text { Long Bridge } \\
\text { in Szczecin }\end{array}$ & -5.123 & 459 & 512 & 587 \\
\hline Trzebież & -5.080 & 456 & 510 & 583 \\
\hline
\end{tabular}

\subsection{Mathematical description of the phenomenon}

The unsteady flow in open channels is most often described by one-dimensional mathematical model, which includes the momentum and mass continuity equations, called de Saint-Venant equations. The form of these equations is as follows $[5,6,7]$ :

$$
\begin{gathered}
\frac{\partial \mathrm{Q}}{\partial \mathrm{x}}+\frac{\partial \mathrm{A}}{\partial \mathrm{t}}=0 \\
\frac{\partial Q}{\partial x}+\frac{\partial}{\partial x}\left(\frac{Q^{2}}{A}\right)+g A \frac{\partial h}{\partial x}+\frac{Q||^{2} g}{R_{H}^{4 / 3} A}=0
\end{gathered}
$$

The above system of equations due to its character can be solved using $[8,9,10]$ :

- method of characteristics;

- finite difference method;

- finite element method.

Engineering practice showed high efficiency of finite differences using the 4-point implicit differential Preissman scheme $[11,12,13]$. Among all differential schemes, the scheme proposed in 1961 by Preissman is one of the most frequently used in the calculations of flows in rivers and open channels. The Preissman scheme assumes that from discretized solution area in the form of space-time node grid selects a single mesh with dimension $\Delta \mathrm{t} \times \Delta \mathrm{x}$. In the middle of that mesh the differential equation approximation is made for any point. Location of that point is defined by the values of the numerical coefficient: $\omega$ - time weight coefficient and $\psi$-space weight coefficient. 


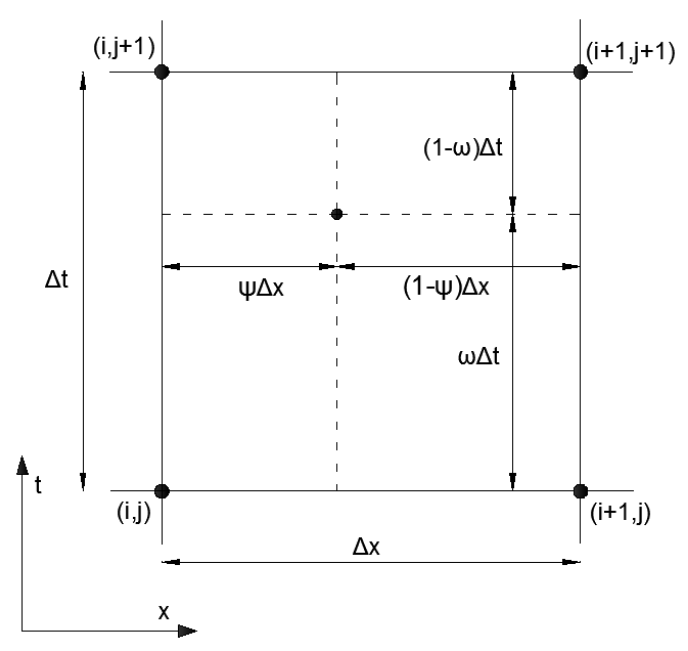

Fig. 3. Fragment of nodes grid for a four-point scheme.

For above scheme, the approximation formulas as follows:

$$
\begin{gathered}
f_{p}(x, t) \approx \psi\left[\omega f_{j}^{i+1}+(1-\omega) f_{j}^{i}\right]+ \\
(1-\psi)\left[\omega f_{j+1}^{i+1}+(1-\omega) f_{j+1}^{i}\right] \\
\frac{\partial f}{\partial \mathrm{x}} \approx(1-\omega) \frac{f_{j+1}^{i}-f_{j}^{i}}{\Delta x_{j}}+\omega \frac{f_{j+1}^{i+1}-f_{j}^{i+1}}{\Delta x_{j}} \\
\frac{\partial f}{\partial t} \approx \psi \frac{f_{j+1}^{i}-f_{j}^{i}}{\Delta t_{i}}+(1-\psi) \frac{f_{j+1}^{i+1}-f_{j}^{i+1}}{\Delta t_{i}}
\end{gathered}
$$

where:

$\omega$ - time coefficient;

$\psi$ - spatial coefficient.

As can be seen, coefficients are important for the quality of the solution approximations, including its stability. The analysis of convergence and stability of the Preissman scheme was carried out by Abbot [14]. Ligget and Cunge [15] showed that for weight coefficients greater than 0.5 the scheme is always stable. In 1987 using the von Neumann condition:

$$
\frac{1}{C_{R}}(\psi-0.5)+(\omega-0.5) \geq 0
$$

developed a relationship between weighting coefficients and stability of solutions, as shown in Figure 4.

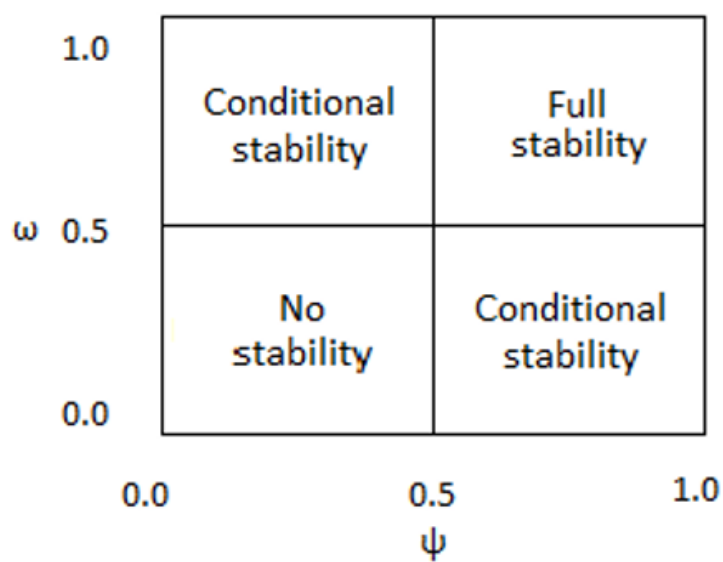

Fig. 4. Stability of the Preissman scheme as a function of the weight coefficients.
The value of $C_{R}$ in the von Neumann condition means the Courant number:

$$
\begin{gathered}
C_{R}=\frac{\Delta t}{\Delta x} \sqrt{g h} \\
C_{R}<0
\end{gathered}
$$

Courant number is a dimensionless parameter specifies the maximum time step that can be defined in the model to maintain the stability of solutions. In case of Preissman scheme, which is implicit scheme, the condition of Courant-Friedrichs-Lewy (8) is not required [16]. Despite the conclusions presented by Lyn and Goodwin, the stability of the solutions should also be ensured by proper selection of initial conditions, which should be correspond to the boundary conditions. Lack of proper matching can result in at least the wrong solutions. Ewertowski [17], on the example of Nysa Kłodzka, analyzed the impact of the mismatch between boundary and initial conditions. He determined that regardless of the research area, there would always be some mismatch of results obtained from steady flow model being boundary conditions in unsteady flow model. The time of impact of mismatch of initial conditions in relation to the boundary conditions for rivers and open channels can be up 32 hours.

\section{Model description}

Over the years, many computer programs have been developed which can solve flow issues in open channels in one, two and three-dimensional. The current version of Hec-Ras (Hydrologic Engineering Center - River Analysis System) allows to calculate the flow issues in one and two-dimensional, the issues of sediment and pollution transport. Therefore, Hec-Ras is one of the most popular program, and then it is the basic calculation tool in this work. River network in Hec-Ras can be treated as a set of individuals sections of channels connected together in junctions. Built model assumes a section of the Odra river from Widuchowa village to cross-sections at Regalica and Odra Pucka, directly after the Green channel. Author deliberately limited the modelling area, excluding from calculation area contain between the Green Channel and Roztoka Odrzańska. The reason for the limitation was the author's conviction that in order to carry out analyzes in this work, the limited area is satisfying. From the early 1970s, when the first computers had begun and were not yet available the software of river network structures hydraulic modelling, scientists of the Institute of Water Engineering at the Szczecin University of Technology developed 4 models: 1. developed by prof. J. Boczar's research team in 1975 [18],

2. developed by dr. S. Orlewicz's research team in 1980 [19],

3. dr. R. Ewertowski's model created as part of his doctoral thesis in 1983 [11],

4. dr J. Kurnatowski's model built in 1983 r [20].

Authors model, in contrast to previously built in the past 4 models of the lower Odra network assumes the possibility of retention of Miedzyodrze area, which is 
possible by occurrence of three independent detention polders at Międzyodrze - fig. 5:

- south detention polder (Widuchowa polder) - 1a, 1b,

- middle detention polder (Gryfino polder) - 2,

- north detention polder (Szczecin polder) - 3 .

Division into detentions basin areas of Międzyodrze took place as a result of the construction of embankments under the roads, which make that all three polders work independently of each other. Due to "slenderness" of the southern basin, for the purpose of modelling, it was divided into two cooperating basins. This model consists 14 section of rivers and channels connected in 8 junctions.

The sections of rivers and channels are represented by 1637 cross-sections. Total length of all sections is over $81 \mathrm{~km}$.

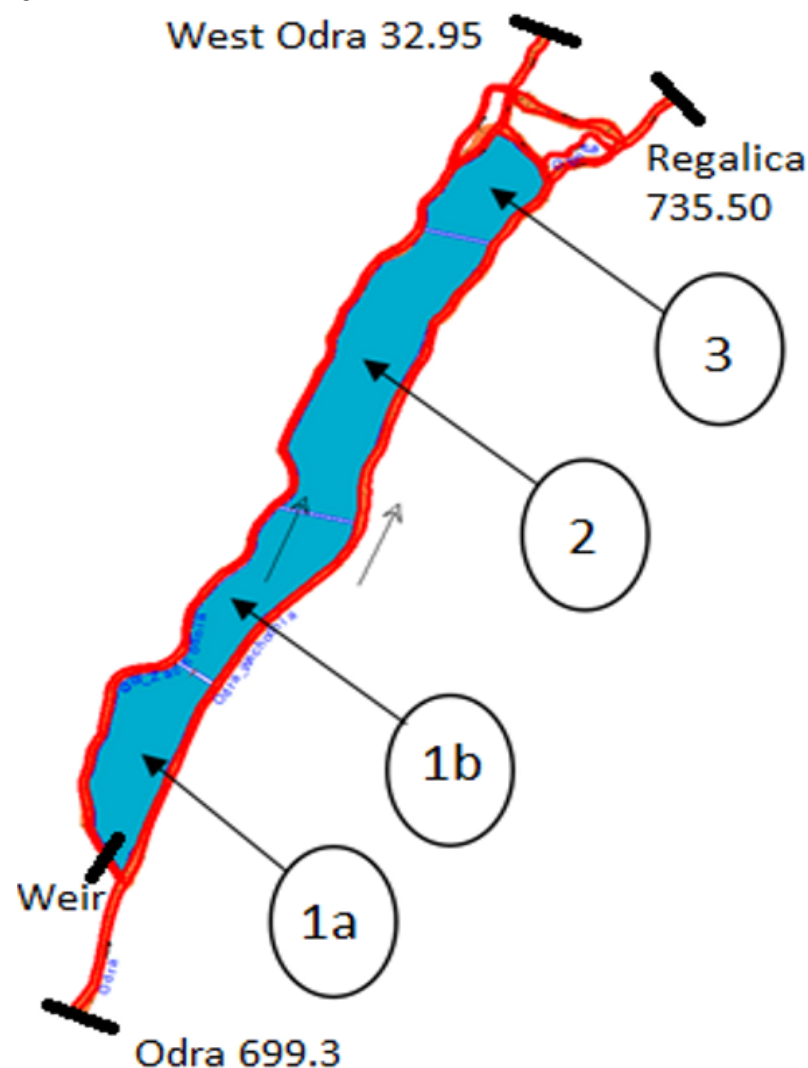

Fig. 5. Structure of lower Odra river network.

\section{Preparing calculation}

The choice of boundary conditions in the modelling of hydrological processes is always very important and complicated issue. In lower Odra model can determinate four places where boundary conditions are defined, whose location are shown in figure 5:

- Input cross section in model (cross section at $699.3 \mathrm{~km}$ of Odra) - boundary condition is defined in the form of flow hydrograph;

- Output cross sections in model (cross sections at $735.50 \mathrm{~km}$ of Regalica and $32.95 \mathrm{~km}$ of West Odra) boundary conditions are defined in the form of stage hydrographs;
- Widuchowa weir - boundary cross section is defined by degree of opening of spans.

The basis for selection of boundary conditions in this paper are characteristic values. Due to the fact that in the lower Odra cross-sections in most cases it is not possible to determine the stage-flow relationship, there is a high flexibility in choosing the hydrological scenario. In paper three steady and two unsteady in time hydrological scenarios have been prepared. Scenarios 1, 2 and 3 appropriately represents flows of SNQ, SSQ and SWQ, and appropriately stages: SNW, SSW and SWW. The values of hydrological scenarios steady in time are presented in table 2 .

Table 2. Steady in time values.

\begin{tabular}{|c|c|c|}
\hline Scenario & $\begin{array}{c}\text { Flows in } \\
\text { input }\left[\mathrm{m}^{3} / \mathrm{s}\right]\end{array}$ & $\begin{array}{c}\text { Stages in } \\
\text { output [m a.s.1.] }\end{array}$ \\
\hline Scenario 1 & 252 & -0.533 \\
\hline Scenario 2 & 535 & -0.003 \\
\hline Scenario 3 & 1251 & 0.747 \\
\hline
\end{tabular}

In case of unsteady flow, two types of floods were analyzed, i.e. river flood (due to increased flow) and storm flood. Hydrograms of stages and flows of scenarios 4 and 5 are shown in Figures 6 and 7. In case of scenario 4, the input flow in the first five hours is equal to SNQ, then it increases to SWQ in 9 hours. Then, to 18 hour flow decreases again to the value SNQ, which is steady to the end of simulation. Similar character has scenario 5, which presents a storm flood

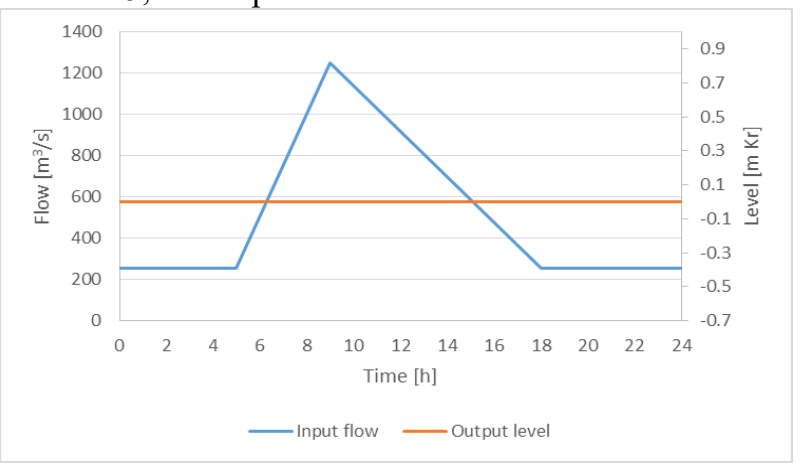

Fig. 6 Hydrological scenario No. 4 - SH4.

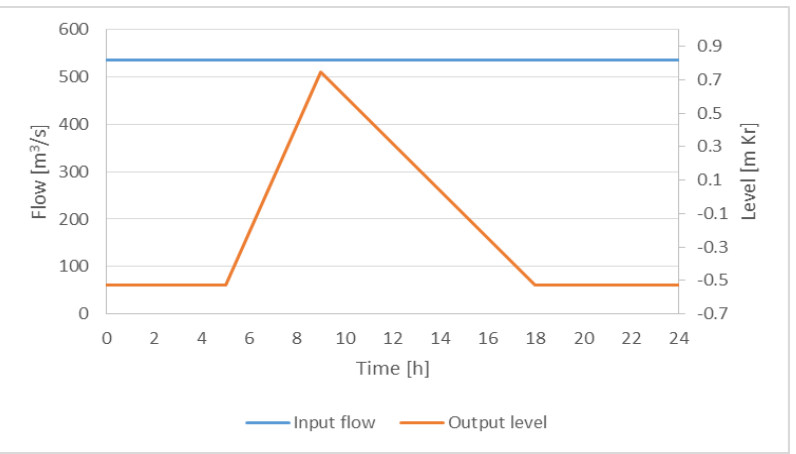

Fig. 7 Hydrological scenario No. 5 - SH5. 


\section{Calibration and verification of the model}

One of the inherent stages of construction of hydrological models is the process of calibration and then verification of the model. In both processes were used two independent sets of measured data. The aim of calibration was identification of Manning roughness coefficients, that values between measured and calculated flows were close as possible. Calibration were carried out for the one of most important area in the lower Odra river network, i.e. the area of main connection of both Odra branches by the Skośnica channel. Simplified scheme of this area is shown on figure 8 . The average percentage error was approx. $4 \%$.

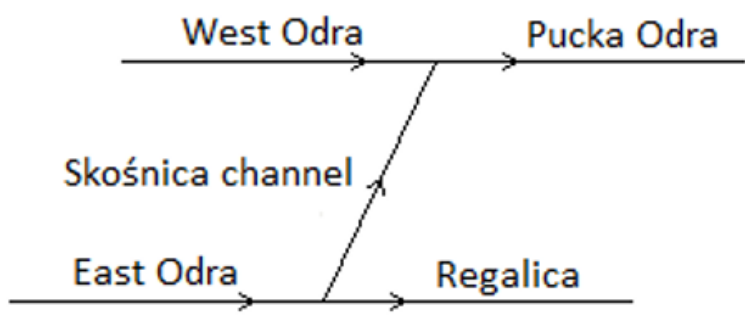

Fig. 8 Lower Odra river structure for calibrations.

The result of the calibration of constructed model was a cure presented the relationship between the input flow to the network and the value of the Mannings roughness coefficient. The obtained curve confirms the results of previous studies on determining the friction forces in lower Odra, which were carried out by Kurnatowski [3]

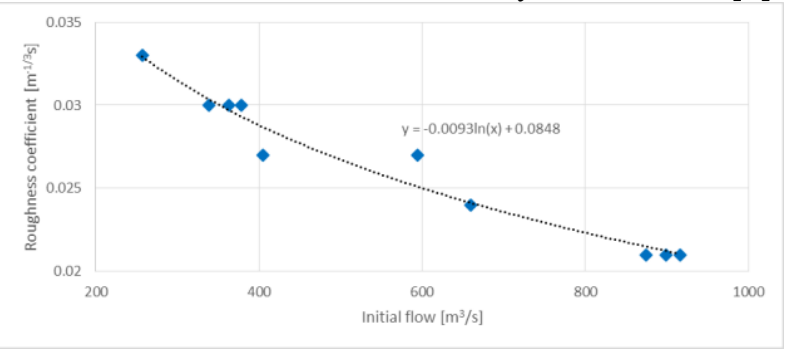

Fig. 9. Changes in Manning roughness as a function of the input flow (based on calibration data set).

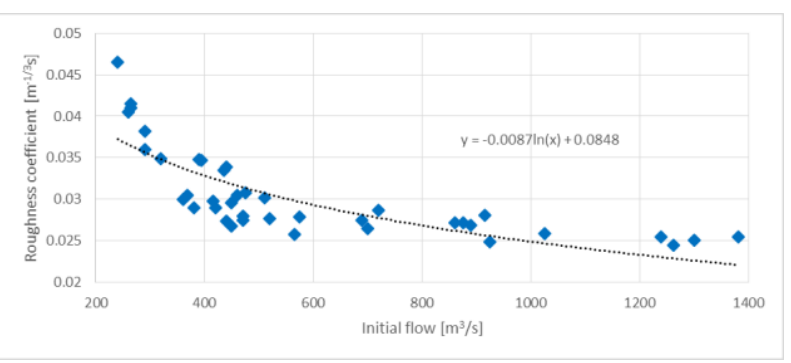

Fig. 10. Changes in Manning roughness as a function of the input flow by Kurnatowski [3, 21].
Process of verification of the model was checking the calculated and measured water levels in the area of Widuchowa weir. Verification showed the average difference between measured and calculated values was approx. $5 \mathrm{~cm}$. In the author's opinion, these differences are admissible, which allowed to implement the model.

\section{Calculation}

\subsection{Initial assumptions}

The main task in proper selection of weight coefficients (time and spatial) of the Preissman scheme is to ensure the stability of the solution. Due to the limitations imposed by the developers of Hec-Ras, the program user is only able to change the only time weighting coefficient and only in range from 0.6 to 1.0. Spatial (fig. 4) coefficient obligatory imposed by the Hec-Ras developers is 0.5 . Flow simulations were carried out with the following calculations parameters:

- calculation time step: $12 \mathrm{~s}$;

- calculation accuracy of the water level elevations:

- in rivers and channels: $0.0005 \mathrm{~m}$;

- in basins: $0.005 \mathrm{~m}$;

- calculation accuracy of flows : $0.005 \mathrm{~m}^{3} / \mathrm{s}$;

- maximum of iterations: 30 .

The analysis of impact of space weight coefficient was limited to the analysis of changes in flow values in selected cross-sections of Odra river:

- East Odra in $704.1 \mathrm{~km}$ - beginning of East Odra - EO 704.1;

- Skośnica channel in $0.50 \mathrm{~km}-\mathrm{S} 0.50$;

- Odra Pucka in $32.95 \mathrm{~km}$ - OP 32.95- one of two mouth of models.

The key step in flow simulations in rivers and open channels is the process of equalization the boundary conditions to the initial conditions, which in the Hec-Ras software is defined in the form of flows at the initial moment. In this paper, the author intentionally did not match the initial and boundary conditions. Author wanted to determine of impact these parameters on process of disappearing of mismatches of these conditions.

\subsection{Calculations results}

Figures 11-13 shows the values of steady in time flows and stages for selected cross section. 


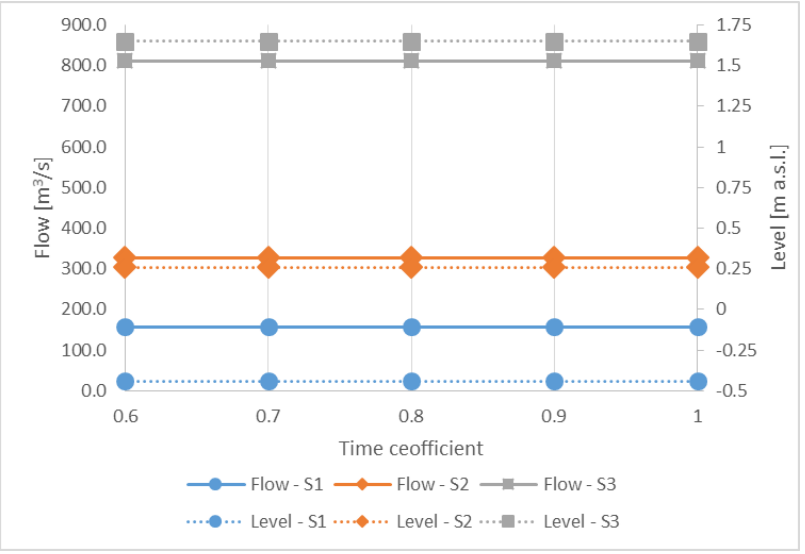

Fig. 11. Flows and stages values for East Odra in $704.12 \mathrm{~km}$.

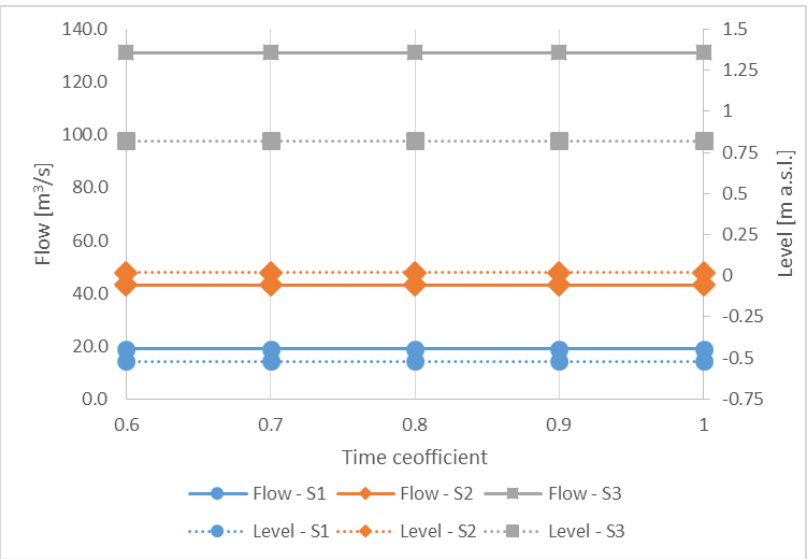

Fig. 12. Flows and stages values for Skośnica channel in 0.50 $\mathrm{km}$.

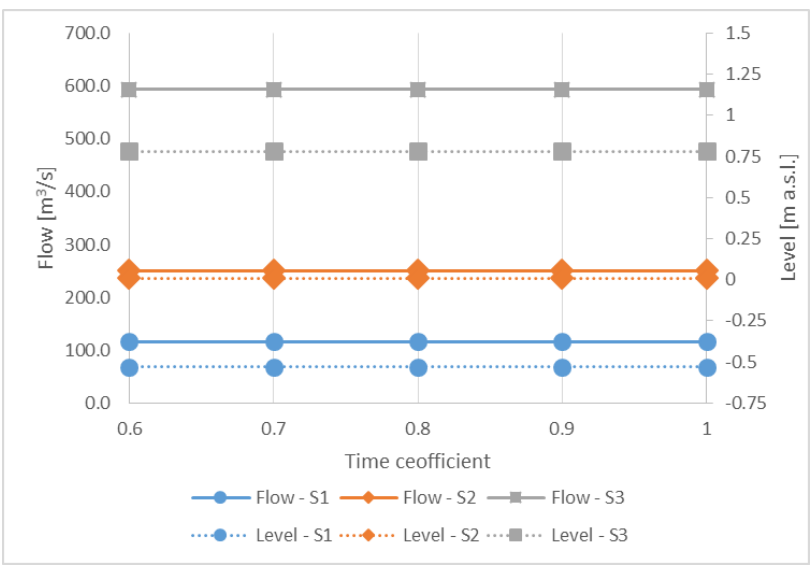

Fig. 13. Flows and stages values for Odra Pucka in 32.95 .

As can be seen in the above figures, the spatial coefficient of the Preissman scheme does not affect on flows and water levels in the river network in case of steady flow. Figures 14-17 show hydrograms of flows and water levels for selected cross section, with a weighting coefficient equal to 0.6 .

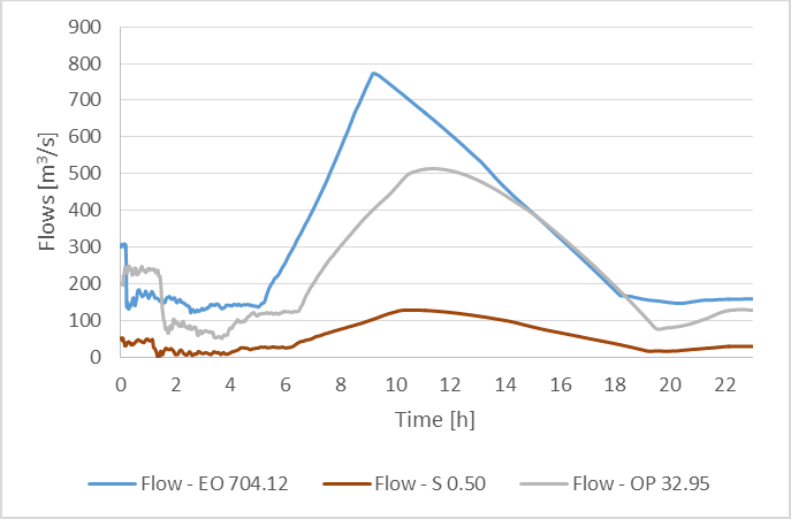

Fig. 14. Calculated flows hydrograms - SH4.

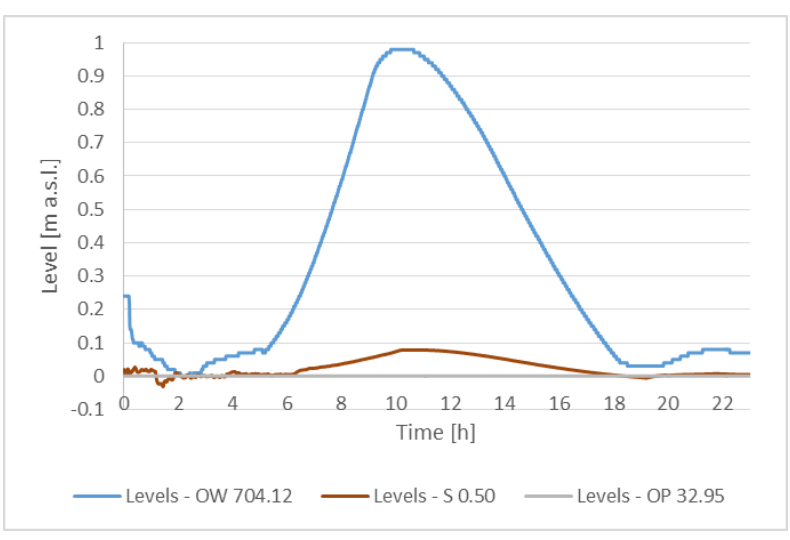

Fig. 15. Calculated stages hydrograms - SH4.

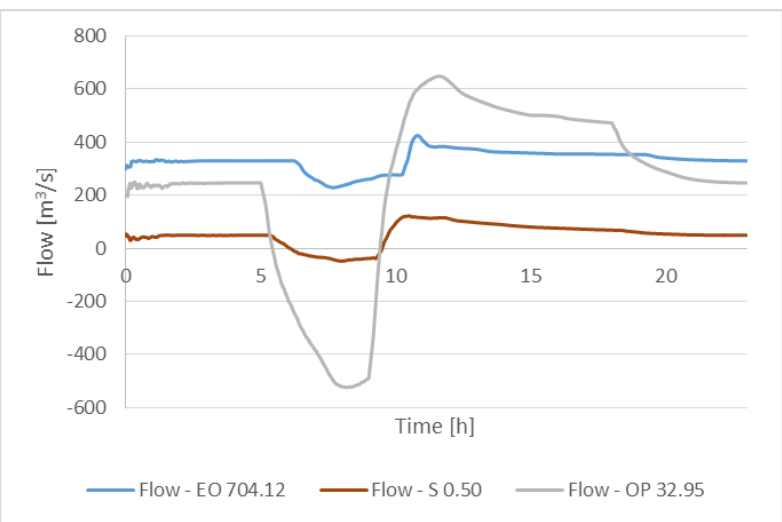

Fig. 16. Calculated flow hydrograms - SH5.

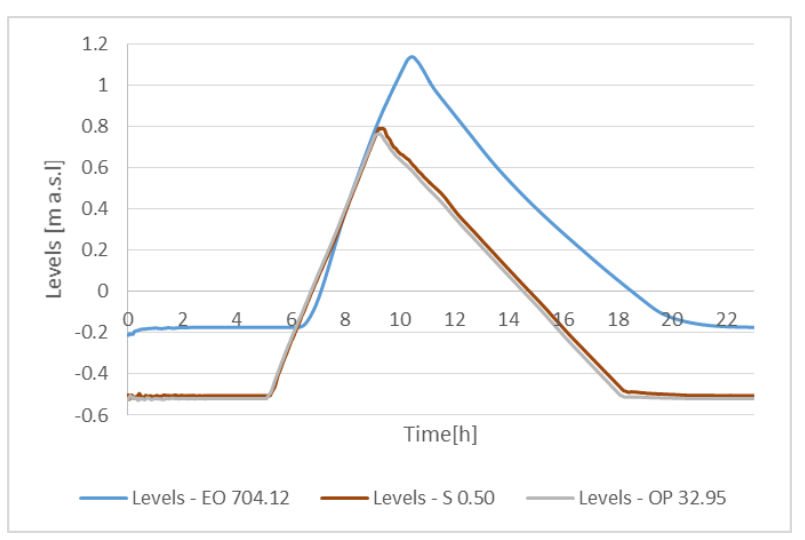

Fig. 17. Calculated stages hydrograms - SH5 
Table 3 shows the results of differences in the volume of hydrograms in relation to the volume of the hydrograms with a coefficient of 0.6 .

Table 3. Comparison of hydrograms volumes in selected cross sections.

\begin{tabular}{|c|c|c|c|c|c|}
\hline \multirow{2}{*}{ 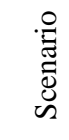 } & \multirow{2}{*}{$\begin{array}{l}\text { Cross } \\
\text { section }\end{array}$} & \multicolumn{4}{|c|}{$\begin{array}{c}\text { Difference in the volumes of } \\
\text { hydrograms [\%] }\end{array}$} \\
\hline & & 0.7 & 0.8 & 0.9 & 1.0 \\
\hline \multirow{3}{*}{ SH4 } & $\begin{array}{l}\text { East Odra } \\
704.12\end{array}$ & $<0.001$ & 0.002 & 0.002 & 0.002 \\
\hline & $\begin{array}{l}\text { Odra Pucka } \\
32.95\end{array}$ & 0.015 & 0.024 & 0.032 & 0.04 \\
\hline & $\begin{array}{l}\text { Skosnica } \\
0.50\end{array}$ & $<0.001$ & $<0.001$ & 0.001 & 0.002 \\
\hline \multirow{3}{*}{ SH5 } & $\begin{array}{l}\text { East Odra } \\
704.12 \\
\end{array}$ & 0.006 & $<0.001$ & $<0.001$ & $<0.001$ \\
\hline & $\begin{array}{c}\text { Odra Pucka } \\
32.95\end{array}$ & $<0.001$ & $<0.001$ & $<0.001$ & $<0.001$ \\
\hline & $\begin{array}{c}\text { Skosnica } \\
0.50\end{array}$ & 0.007 & 0.004 & 0.003 & 0.003 \\
\hline
\end{tabular}

The values presented in the above table showed that the changes in the spatial coefficient of Preissman scheme does not significantly affect on values of flows in river network of the lower Odra.

\section{Conclusions}

1. The analyses presented in the paper showed that the change in weight of the Preissman scheme coefficient does not affect on distribution of flows in the lower Odra river network, both at steady and unsteady flow conditions.

2. Analyzes of modelling of flows in the lower Odra river network have shown that the value of time coefficient does not affect on the phenomenon caused by the mismatch of the initial and boundary conditions in form of flows in input and stages in output (table 2). It can be assumed that this is due to high values of flows in Odra river. Similar analyses should be carried out for smaller river networks with a much smaller flow values but higher velocities.

3. The Hec-Ras software is not good tool to comprehensively determine the impact of both weighting coefficient used in the four-point implicit Preissman scheme, because the developers of Hec-Ras do not allow for that. Hec-Ras limits analysis only to the influence of time-weight coefficients.

4. Despite the lack of calculation of influence of time coefficient occurring in Preissman scheme, it can be assumed that also it will not bring significant differences in flows values. However, to confirm this words, should be used the software that allows in complex modification of 4-point Preissman scheme in range of values of weighting coefficient. Unfortunately, author does not know the software that allow for user to change the coefficient of Preissman scheme, therefore one of the possibilities is to create own software or script (built in Matlab or MS Excel).

\section{References}

1. R Mańko, PhD Thesis, West Pomeranian University of Technology, Supervisor: Ryszard Ewertowski (2018)

2. J. Wira, R. Mańko, Zeszyty Naukowe Inżynieria Lądowa i Wodna W Kształtowaniu Środowiska 14 (2016)

3. J. Kurnatowski, Wybrane problemy obliczeń ruchu wód $w$ sieciach rzecznych o strukturze pierścieniowej na przyktadzie dolnej Odry, (Wydawnictwo Uczelniane Zachodniopomorskiego Uniwersytetu Technologicznego w Szczecinie, Szczecin, 2011)

4. A. Kreft (red.), Informator nawigacyjny śródlądowych dróg wodnych granicznego i dolnego odcinka Odry (WFOŚiGW, Szczecin, 2009)

5. J. Sawicki, Przeplywy ze swobodna powierzchnia (PWN, Warszawa, 1998)

6. R. Szymkiewicz, Journal of Hydrology 176, (1996)

7. R. Szymkiewicz, Modelowanie matematyczne przeptywów $w$ rzekach I kanałach (PWN, Warszawa, 2000)

8. V. Kantorowicz, International Conference of Numerical Modelling of River (Bratislava, 1981)

9. J. Granatowicz, R. Szymkiewicz, Archiwum Hydrotechniki XXXVI, vol. 3-4 (1989)

10. R. Szymkiewicz, Journal of Hydrology 122 (1991)

11. R. Ewertowski, PhD Thesis, Warsaw Univeristy of Technology, Supervisor: R. Jasiewicz (1983)

12. K.W. Chau, IAHS Publ. 193 (1990)

13. R. Szymkiewicz, Journal of Hydrology 147 (1993)

14. M. Abbot, Water Resources Publications 1 (1975)

15. J. Ligget, J. Cunge, Water Resources Publications 1 (1975)

16. M. Pluta, PhD Thesis, Szczecin University of Technology, Supervisor: Zygmunt Meyer (1994)

17. R. Ewertowski, Regionalne problemy gospodarki wodnej $i$ hydrotechniki (Wydawnictwo Uczelniane Politechniki Szczecińskiej, Szczecin, 2006)

18. J. Boczar, B. Sajko, J. Ziebro, Badania Hydrauliczne, Prace Naukowe Politechniki Szczecińskiej 41 (1975)

19. S. Orlewicz, W. Buchholz, J. Kurnatowski, Z. Mroziński, Prace Naukowe Politechniki Szczecińskiej 22 (1980)

20. J. Kurnatowski, Prace Naukowe Politechniki Szczecińskiej 29 (1989)

21. J. Kurnatowski, Regionalne problemy gospodarki wodnej $i$ hydrotechniki (Wydawnictwo Uczelniane Politechniki Szczecińskiej, Szczecin, 2004) 